\title{
Hacettepe Üniversitesi Tıp Fakültesi Dönem VI Öğrencilerinin Tıp Fakültesinde Hekimlik Becerileri Eğitimine Yönelik Görüşleri
}

\section{The Views of Senior Medical Students'About The Medical Skills Traning at The Hacettepe University Faculty of Medicine}

\author{
${ }^{1}$ Bürge Atılgan (Orcid id : 0000-0002-2800-4957) \\ ${ }^{2}$ Furkan Temizayak (Orcid id : 0000-0002-9129-1290) \\ ${ }^{2}$ Tuğçe Çă̆ıran (Orcid id : 0000-0003-3012-6600) \\ ${ }^{2}$ Onur Ege Tarl (Orcid id : 0000-0002-0341-4407) \\ ${ }^{3}$ Gökçe Gürler (Orcid id : 0000-0003-3073-4438) \\ ${ }^{2}$ Mehmet Cem Müderrisoğlu (Orcid id : 0000-0002-4407-5640) \\ ${ }^{1}$ Gülşen Taşdelen Teker (Orcid id : 0000-0003-3434-4373) \\ ${ }^{1}$ Sevgi Turan (Orcid id : 0000-0001-9287-0641) \\ ${ }^{3}$ Iskender Sayek (Orcid id : 0000-0001-5951-3511) \\ ${ }^{1}$ Hacettepe Üniversitesi Tıp Fakültesi, Tıp Eğitimi ve Bilişimi AD. \\ ${ }^{2}$ Hacettepe Üniversitesi Tıp Fakültesi \\ ${ }^{3}$ Tıp Eğitimi Programlarını Değerlendirme ve Akreditasyon Derneği \\ Sorumlu Yazar: Sevim Bürge Çiftçi Atılgan \\ Hacettepe Üniversitesi Tıp Fakültesi, Tıp Eğitimi ve Bilişimi AD Sıhhiye, Ankara \\ Tel: 03123052617 e-posta: burgeatilgan@hacettepe.edu.tr
}

Anahtar Sözcükler: İntörn hekim görüșleri, hekimlik becerileri, mesleki kaygı

Keywords: Interns' views, fundamental medical skills, anxiety of becoming $a$ physician,

Gönderilme Tarihi Submitted:20.09.2019

Kabul Tarihi

Accepted: 15.12.2019

\section{ÖZET}

Amaç: Tıp fakültelerinin sorumluluğu, yaşadığı toplumu tanıyan, toplumun sağlık sorunlarına duyarlı, önleyici ve tedavi edici sağlık hizmetleri sağlayabilen mezunlar yetiştirmektir. Güvenli sağlık hizmeti sunması ve toplumun sağlık düzeyini iyileştirmesi beklenen mezunların tamamının temel hekimlik değerleri ve hekimlik becerilerine sahip olmaları sağlanmalıdır. Bu çalışmanın amacı Hacettepe Üniversitesi Tıp Fakültesi (HÜTF) intörn hekimlerinin, Ulusal Tıp Eğitimi Çekirdek Programında (UÇEP) belirtilen ve ulaşılması istenen temel hekimlik becerilerine ulaşma düzeylerine ilişkin görüşlerini değerlendirmektir.

Gereç ve Yöntem: Çalışmanın yapıldığg 2017-2018 öğretim yılında HÜTF' deki intörn hekimlerin \%39,3'ü $(n=455)$ araştırmaya katılmıştır. Hekimlik ile ilgili tutum ve alışkanlıklara yönelik görüşleri ve

Künye: Atılgan B, Temizayak F, Çăğran T, Tarı O, Gürler G, Müderrisoğlu $M$ ve ark. Hacettepe Üniversitesi Tıp Fakültesi Dönem VI Öğrencilerinin Tip Fakültesinde Hekimlik Becerileri Eğitimine Yönelik Görüşleri. 2020;19(57):5-25 
UÇEP, yer alan temel hekimlik uygulamalarını izleme, yapma ve yapabilme durumlarına dair öz değerlendirmeleri 192 sorudan oluşan bir anket yardımı ile değerlendirilmiştir.

Bulgular: Anket sonuçlarına göre öğrencilerin tamamına yakını uzman hekim olmayı istemekte ve dershaneye gitmektedir. Mesleki uygulamaları yapabilme konusundaki kayg1 düzeyleri oldukça yüksektir. Mezunların tamamı tarafından kazanılmış olması beklenen UÇEP'te yer alan becerilerin bütününe bakıldığında yaklaşık \%20-25 arasında izleme, yapma, yapabilme durumlarında kayıplar olduğu görülmektedir.

Sonuç: Çalışma, mezuniyetlerine birkaç ay kalmış öğrencilerin UÇEP'te tanımlanmış temel hekimlik becerilerine göre birinci basamak sağlık hizmetleri için yeterli olmadıklarını göstermiştir. Öğrencilerin yetersiz olduğu becerilerin eğitim programının hangi süreçlerinde yer aldığı ve yetersizlik nedenlerinin araştırılması gerekir. Program değerlendirme çalışmaları ile sorunlar belirlenerek iyileştirilmesine yönelik önlemler alınmalı ve yapılanma sürecinin her aşamasına sürecin öznesi olan öğrenci ve mezunlar dahil edilmelidir. Ayrıca eğitim programlarının tam yeterli mezun hekimler yetişmesi amacına hizmet etmesi, bunun yanı sıra öğrencilerin kendilerine ilişkin yargılarının olumlu hale getirilmesi ve öğrencilere mesleki yaşantı ile ilgili motivasyon ve özgüven kazandırılması önemlidir.

\section{ABSTRACT}

Background: The responsibility of the medical faculties is to educate graduates who are aware and sensitive to the health problems of the society and who can provide preventive and therapeutic health services. All graduates who are expected to improve the health level of the society should be provided with fundamental medical values and medical skills. The aim of this study is to evaluate the views of interns of Hacettepe University Faculty of Medicine on the level of achievement of fundamental medical skills stated in the National Medical Education Core Program (NMCP).

\section{Methods}

In the 2017-2018 academic year, 39.3\% ( $n=$ 455) of senior medical students participated in the study. Their views on attitudes and habits related to medicine and their self-assessments about observing, performing and being able to do basic medical practices after graduation which are stated in the NCMP were evaluated consisting of 192 questions.

\section{Results}

According to the results of the survey, almost all of the students want to be specialist and go to the commercial courses. Anxiety level about performing medical practices after graduation is quite high.

When the total of the skills in the NMCP, is reviewed, it is seen that there is a loss of observing, performing and being able to do after graduation between 20-25\%.

\section{Conclusions}

The study showed that some of the senior medical students who were a few months away from graduation were not sufficient for primary health care services according to the fundamental medical skills defined in the NMCP. It is necessary to investigate which the skills are inadequate and the reasons for the inadequacy. It is also important to make the students' positive judgments about themselves and to give them motivation and self-confidence about their professional life. 


\section{GİRIŞ}

T1p eğitiminin hedefi, ülkesinin sağlık sorunlarına duyarlı, çözüm üretebilecek kapasitede yaşam boyu gelişimlerini sürdüren hekimler yetiştirilmesini sağlamaktır. Edinburg Bildirgesi’nde (1988) tıp eğitiminin amacı; "tüm insanların sağlık düzeylerini yükseltecek hekimler yetiştirmek" olarak belirtilmiştir (1). Tıp eğitimi için 1999'da kurulan Uluslararası Tıp Eğitimi Enstitüsü (IIME), tıp eğitiminin temel amacının, toplumun sağlık gereksinimlerini karşılayabilecek ve hızla değişen tıp uygulamalarına uyum sağlayacak doktorları geleceğe hazırlamak olduğunu belirtmiştir (2). Uluslararası Tıp Eğitimi Enstitüsü Çekirdek Komitesi 'Global Minimum Essential Requirements in Medical Education' dokümanında, tüm dünyada ülkelerin tıp fakültelerinden mezun olacak hekimler için 'temel öğrenme çıktıları' belirlenmiştir (2). Bu çıktılara benzer şekilde Accreditation Council for Graduate Medical Education (ACGME), General Medical Council, World Health Organization (WHO), The Canadian Medical Education Directives for Specialists (CanMeds) gibi kurullar hekimlerin temel yetkinliklerini tanımlamışlardır (2). Türkiye'de temel tıp eğitiminde kazanılması gereken yetkinlikler ise Tıp Eğitimi Programlarını Değerlendirme ve Akreditasyon Derneği (TEPDAD) tarafindan profesyonel, sağllk savunucusu, ekip üyesi, danışman, yönetici lider, bilim insanı, iletişimci olarak tanımlanmıştır (3).

Nitelikli hekim yetiştirme çabasında olan tıp eğitimi programları ülke gerçeklerine ve bilimsel temellere dayanarak oluşturulmalı ve sürekli sorgulanmalıdır. Birçok araştırma göstermiştir ki öğrenci görüşü, geribildirimi veya memnuniyeti olarak adlandırılan uygulamalar fakültelerin eğitim süreçlerini değerlendirme, düzenleme ve geliştirmede en sık kullanılan yöntemler arasında yer alır. (4-6). Yapılan çalışmalarda öğrenci geribildirimlerinin öğrenci merkezli eğitimin ana unsuru ve tıp eğitiminde önemli bir değerlendirme yöntemi olduğu belirtilmektedir (7-10). Araştırmacilar, değerlendirme sonuçlarının öğretimin kalitesini arttırmada yardımc1 olduğu konusunda hemfikirdir $(11,12)$. Tip fakültelerinde eğitime ve programlara yönelik yapılan araştırmalarda, öğrenci görüş ve geribildirimleri önemsenmekte ve değerlendirme sonuçları, eğitimin şekillendirilmesinde yol gösterici olarak kullanılmaktadır $(5,13,14)$.

1991 yılında Türkiye Büyük Millet Meclisi tarafindan tıp fakültelerinden mezun olan intörn hekimlerin mesleki rollerini başarı ile yapabilmeleri için gerekli bilgi, beceri, tutum ve alışkanlıklara sahip olup olmadıklarını tespit etmek, varsa yetersizliklerin nedenlerini bulmak ve gerekli tedbirleri almak amaciyla Meclis araştırma komisyonu kurulmuştur. $\mathrm{Bu}$ komisyon öncülüğünde bu konuda kapsamlı bir çalışma yapılmıştır. Türkiye'de tıp eğitiminin öğrenci boyutuyla, öğretim üyesi boyutuyla ve yönetim boyutuyla değerlendirildiği üç ciltlik bir araştırma raporu hazırlanmıştır. Araştırma raporunun öğrenci boyutuyla değerlendirmenin yapıldığı ve öğrenci görüşlerinin yer aldığ kısmında; ülkemizde verilen tıp eğitiminin yeterli olmadığı, öğrencilerin kendilerini bilgi ve beceri açısından hazır hissetmedikleri vurgulanmıştır (15). İntörn hekimlerle 2001 yılında yapılan bir çalışmadaki bulgular da tıp fakültesinin eğitim programının, yeni mezun olmuş hekimlerin birincil sağlı hizmetleri için gerekli bilgi ve becerileri kazandırma beklentilerini karşılamadığını göstermiştir (16). Ankara Valiliği İl Sağlık Müdürlüğü'ne bağlı birinci basamak sağlık kurumlarında görev yapan hekimlerle yapılan bir araştırmada tıp fakültesinden mezun olan hekimlerin önemli bir 
kısmının birinci basamak sağlık hizmetlerinin yürütülmesinde görev almakta olduğu, ancak birinci basamak sağlık kurumlarında çalışan hekimlerin önemli kısmının, aldıkları eğitimi orta düzeyde yeterli ve yetersiz buldukları görülmüştür (17). Tıp fakültesi son sınıf öğrencilerinin, şimdiye kadar aldıkları eğitim ve kazandıkları beceriler hakkındaki düşüncelerini değerlendirmek ve eğitimle ilgili düzenlemelerde bu bilgilerden yararlanmak amacıyla yapılan bir çalışmada, araştırmaya katılanların yaklaşık yarısının temel tıbbi ve cerrahi girişimlerde kendilerini yetersiz olarak değerlendirdikleri, araştırma kapsamına alınan öğrencilerin $\% 98,4$ 'ünün bir alanda uzmanlık eğitimi almak istediği, \%47,8'inin ise bir süre pratisyen hekim olarak çalışmayı düşündüğü belirtilmiştir. Uzman hekim olmayı düşünmelerinin en önemli nedenleri olarak sırasıyla; parasal tatmin, mesleki doyum, sosyal statü, bir alana özel ilgi duyma ve akademik kariyer yapma isteği olarak gösterilmiştir (18). 2004-2005 öğretim yılının başında ve sonunda Hacettepe Üniversitesi Tıp Fakültesi (HÜTF) dönem VI öğrencilerinin UÇEP'te tanımlanmış beceri ve tutumlara sahip olma durumlarının belirlenmesi amacıyla yapılan bir araştırmada intörn hekimlik sonunda beceri düzeyinde artış olsa da yeterli düzeye çıkarılamamış olduğu görülmüştür $(19,20)$. Literatürde dikkat çeken diğer bir sonuç 1991-2005 yılları arasındaki çalışmalarda intörn hekimler tarafindan bildirilen eğitim döneminde yapılan hekimlik becerileri uygulama sayısı az olmasına rağmen, o uygulamayı ileride yapabileceklerini düşünme yüzdelerinin yüksek olmasıdır (15,19). 2017 yılına gelindiğinde ise öğrencilerin uygulamaları eğitim süreçlerinde yapmış olmalarına rağmen ileride uygulayabileceklerine inanma düzeylerinin düşük olduğu görülmektedir (21). Edinburgh'da 1988 yılında toplanan Dünya Tıp
Eğitimi Zirvesi'nde biçimlendirilen 22 eylem önerisinden biri 'Tip Eğitiminin Planlama ve Değerlendirmesine Tip Öğrencilerinin Katılımı'dır. Bildirgede "Tıp eğitiminde öğrencinin yeri yaşamsaldır. Eğitimin her aşamasında; amaçların ve eğitim programının belirlenmesinde, fakülte yönetiminde, eğitim ve sonuçlarının değerlendirilmesinde öğrenci katılımının sağlanması gereklidir" şeklinde vurgulanmıştır (22). Bu araştırmada yukarıdaki çalışmalara ve bildirgelerin önerilerine paralel olarak farklı düzeylerden öğrencilerin katılımı ile oluşturulan bir araştırma ekibi ile mezuniyet öncesi tıp eğitiminin intörn hekimlerin bakış açısıyla değerlendirilmesi amaçlanmıştır. Çalışmada tıp fakültesi öğrencilerinin mesleki rollerini başarıyla yapabilmeleri için gerekli bilgi, beceri ve tutumlara ne derecede sahip olduklarının tespit edilmesine, öğrencilerin tıp eğitiminin yürütülmesine ilişkin görüşlerini ve bunların giderilmesi için gereken önlemlere ilişkin önerilerini belirlenmesine odaklanılmıştır. $\mathrm{Bu}$ doğrultuda araştırmanın amacı:

- Hacettepe Üniversitesi Tip Fakültesi dönem VI öğrencilerinin, hekimlerin Ulusal Tip Eğitimi Çekirdek Programında (28) belirtilen ve ulaşılması istenen temel hekimlik becerilerine ne düzeyde ulaştıklarına ilişkin görüşlerini değerlendirmektir.

\section{YÖNTEM}

Bu çalışma tanımlayıcı nitelikte bir araştırmadır. Hacettepe Üniversitesi Tip Fakültesi'ne 20172018 öğretim y1lında devam eden intörn hekimler (Dönem VI öğrencileri) araştırma grubunu oluşturmuştur. Bu dönemde devam eden 455 intörn hekim bulunmaktadır. Araştırmada örneklem alınmamış tüm intörn hekimlere ulaşılmaya çalışılmıştır. Çalışmaya 186 intörn hekim yanıt vermiştir. Ancak anket formlarının bazılarında çok fazla eksik veri bulunması veya 
yanıtların sağlıklı olmaması sebebiyle 7 anket formu veri dosyasından çıkarılmıştır. Çalışmanın analizi için 179 intörn hekimin anketlere verdiği yanıtlar çalışmaya dahil edilmiştir. Çalışmaya katılım \%39,3'tür. Araştırmada üç bölümden (192 soru) oluşan bir anket formu kullanılmıştır. Birinci bölümde eğitim durumları ve sosyodemografik özelliklere ilişkin bilgi toplanmış, ikinci bölümde hekimlik ile ilgili tutum ve alışkanlıklara yönelik görüşler sorulmuş, son bölümde ise öğrencilerin Ulusal Çekirdek Eğitim Programında (28) yer alan temel hekimlik uygulamalarını izleme, yapma ve yapabilme durumlarına dair öz değerlendirme yapmaları istenmiştir. Veriler 2018 yıl1 Mart-Haziran ayları içerisinde toplanmıştır. Öğrencilere ulaşabilmek için yüz yüze ve elektronik anket toplama yönteminin her ikisi de kullanılmıştır. Ayrıca intörn hekimlere ulaşılarak yüz yüze çalışmanın gerekçesi açıklanmış ve akıllı telefonlar üzerinden anket formuna ulaşmaları ve doldurmaları istenmiştir. Yüz yüze görüşmenin yapılmadığ durumlarda ise öğrencilerin hacettepe.edu.tr uzantılı elektronik posta adreslerine araştırma ile ilgili bilgilendirme ve anket bağlantısı gönderilerek veri toplanmıştır. Elde edilen verilerin tanımlayıcı istatistikleri için (yüzde ve ortalamalar1) IBM SPSS 20 yazılımı kullanılarak elde edilmiştir. Araştırmanın uygulanması için Hacettepe Üniversitesi Etik Komisyonundan izin alınmıştır (35853172/431.10_1208 sayılı
HÜ Rektörlük yazısı). Araştırmaya katılımda gönüllülük esas alınmıştır. Uygulama öncesi, araştırma ile ilgili bilgilendirilmiş onam formu aracılığıyla bilgi verilmiş ve öğrencilerin yazılı onamı alınmıştır.

\section{BULGULAR}

Çalışmaya katılan intörn hekimlerin, tıp fakültesini tercih etme nedeni olarak $\% 25{ }^{\prime} \mathrm{i}$ 'topluma yararlı olabilmek', \%21,2'si 'iş garantisi', \%20,1'i 'mesleki kariyer', \%18,2'si 'sosyal statü ve prestij' ve \%14'ü 'aile isteği' yanıtlarını vermiştir. Öğrencilere, üniversite tercihini bugün yeniden yapıyor olsalar yine tıp fakültesi tercih edip etmeyecekleri sorulduğunda $\% 57,3$ 'ü yine tercih edeceğini belirtmiştir. Ayrıca, öğrencilerin üniversite tercihini bugün yeniden yapiyor olsalar yine kendi tıp fakültelerini tercih edip etmeyecekleri sorulduğunda $\% 62,9$ 'u 'evet' yanıtını vermiştir. Çalışmaya katılan intörn hekimlerinin mezuniyet sonrasında \%87,6's1 'yurtiçinde tıpta uzmanlık', \%5,1'i 'yurtdışında tıpta uzmanlık', $\% 2,8$ 'i 'pratisyen hekimlik yapmak' ve $\% 2,3$ 'si 'doktora (PhD) eğitimi' alarak devam etmek istediğini belirtmiş̧ir. Tipta uzmanlık yapmak istediğini belirten öğrencilerin \%41,9'u 'çok istekli', \%33,5'i 'istekli' olduğunu belirtmiştir. İntörn hekimlerin $\% 86,4$ 'ü tıpta uzmanlık sınavına hazırlanmak için 'dershane'ye gittiğini belirtmiştir (Tablo 1). 
Tablo 1. Çalışmaya katılan intörn hekimlerin mezuniyet öncesi ve sonrası kariyer tercihleri

\begin{tabular}{|c|c|c|}
\hline Değișken & Sayı & $\%$ \\
\hline \multicolumn{3}{|l|}{ Tıp fakültesini tercih nedeni $*$} \\
\hline Topluma yararlı olabilmek & 66 & 25,0 \\
\hline İş garantisi & 56 & 21,2 \\
\hline Mesleki kariyer & 53 & 20,1 \\
\hline Sosyal statü ve prestij & 48 & 18,2 \\
\hline Aile isteği & 37 & 14,0 \\
\hline Diğer & 4 & 1,5 \\
\hline
\end{tabular}

\begin{tabular}{|c|c|c|}
\hline \multicolumn{3}{|c|}{$\begin{array}{l}\text { Üniversite tercihini bugün yapıyor olsa yine tıp } \\
\text { fakültesini tercih etme }(n=178)\end{array}$} \\
\hline Evet & 102 & 57,3 \\
\hline Hayır & 76 & 42,7 \\
\hline \multicolumn{3}{|c|}{$\begin{array}{l}\text { Üniversite tercihini bugün yapıyor olsa yine kendi } \\
\text { tıp fakültesini tercih etme }(n=178)\end{array}$} \\
\hline Evet & 112 & 62,9 \\
\hline Hayır & 66 & 37,1 \\
\hline \multicolumn{3}{|c|}{$\begin{array}{l}\text { Mezuniyetten sonra meslek hayatınıza nasıl devam } \\
\text { etmek istiyorsunuz? }(n=177)\end{array}$} \\
\hline Pratisyen hekim & 5 & 2,8 \\
\hline Yurtiçinde tıpta uzmanlık & 155 & 87,6 \\
\hline Yurtdışında tıpta uzmanlık & 9 & 5,1 \\
\hline Doktora (PhD) & 4 & 2,3 \\
\hline Diğer & 4 & 2,3 \\
\hline \multicolumn{3}{|c|}{ Tıpta Uzmanlık yapma isteği $(n=179)$} \\
\hline Hiç istekli değilim & 11 & 6,1 \\
\hline Az istekliyim & 7 & 3,9 \\
\hline Orta derecede istekliyim & 26 & 14,5 \\
\hline İstekliyim & 60 & 33,5 \\
\hline Çok istekliyim & 75 & 41,9 \\
\hline \multicolumn{3}{|c|}{$\begin{array}{l}\text { Tipta Uzmanlık Sınavina hazırlanmak için } \\
\text { dershaneye devam etme }(n=176)\end{array}$} \\
\hline Evet & 152 & 86,4 \\
\hline Hayır & 24 & 13,6 \\
\hline
\end{tabular}

*Soruya birden fazla seçenek ile yanıt verilmiştir. 
Tablo 2. Çalışmaya katılan intörn hekimlerin bilimsel yayınları izleme durumu

\begin{tabular}{lrr}
\hline & Sayı & \% \\
\hline Haftada okunan bilimsel makale sayısı $(\mathbf{n = 1 7 9 )}$ & 126 & 70,4 \\
Hiç & 45 & 25,1 \\
$1-3$ & 4 & 2,2 \\
$4-6$ & 4 & 2,2 \\
10 ve daha fazla & & \\
\hline Yabancı dil bilgisinin tıp alanında bir yayını & 3 & 1,7 \\
okumada yeterliği (n=179) & 18 & 10,1 \\
Hiç & 71 & 39,7 \\
Az & 87 & 48,6 \\
Kismen & & \\
Oldukça iyi & & \\
\hline
\end{tabular}

Tablo 2'de görüldüğü gibi çalışmaya dil bilginiz tıp alanında bir yayını okumada ne katılan intörn hekimlerin \%70,4 gibi büyük derece yeterlidir?' sorusuna intörn hekimlerin bir çoğunluğu 'hiç' makale okumadığını \%17,7'si 'hiç', \%10,1'i 'az', \%39,7'si 'kısmen', belirtmektedir. Öğrencilerin \%25'i haftada ' 1 - \%48,6's1 ise 'oldukça iyi' yanıtını vermiştir 3' makale okuduğunu belirtmiştir. 'Yabancı (Tablo 2). Tablo 3'te yer alan 'hekimlik

Tablo 3. Çalışmaya katılan intörn hekimlerin özgüven ve kaygı durumları

\begin{tabular}{lrr}
\hline Değişken & Sayı & \% \\
\hline Hekimlik uygulamasını başarıyla yapacağınız & & \\
konusunda özgüven (n=179) & - & - \\
Hiç & 11 & 6,1 \\
Az & 49 & 27,4 \\
Kısmen & 96 & 53,6 \\
Oldukça & 23 & 12,8 \\
Çok Fazla & & \\
\hline Mezun olduktan sonra mesleki uygulamaları & & \\
yapmak ile ilgili kaygı düzeyi (n=179) & 14 & 7,8 \\
Hiç & 41 & 22,9 \\
Az & 81 & 45,3 \\
Kısmen & 34 & 19,0 \\
Oldukça & 9 & 5,0 \\
Çok Fazla & & \\
\hline
\end{tabular}


uygulamasını başarıyla yapacağınız konusunda kendinize ne derece güveniyorsunuz?' sorusuna intörn hekimlerin \%27,4'ü 'k1smen', \%53,6's1 'oldukça', \%12,8'i 'çok fazla' yanıtını vermiştir. Soruya 'hiç' olarak yanıt veren olmamıştır.

İntörn hekimlerin 'mezun olduktan sonra mesleğinize yönelik uygulamaları yapmak ile ilgili kaygı düzeyiniz nedir?' sorusuna yanttları \%7,8'i 'hiç', \%22,9'u 'az', \%45,3'ü 'kısmen', $\% 19$ 'u 'oldukça' ve \%5'i 'çok fazla' olmuştur (Tablo 3).

\section{Tablo 4. Çalışmaya katılan intörn hekimlerin mezun olduktan sonra mesleki uygulamaları yapmak ile ilgili ilk üç sıradaki kaygı sebepleri}

\begin{tabular}{lrr}
\hline Kaygı* & Sayı & \% \\
\hline Acil hastayla baş edememe & 119 & 25,1 \\
Mecburi hizmet & 91 & 19,2 \\
Hastayla tek başına baş edememe & 75 & 15,8 \\
Hastalara yanlış tanı koyma & 43 & 9,1 \\
Klinik becerilerde yetersiz kalma & 38 & 8,0 \\
Uzmanlık sinavı sonrası asistanlık süreci & 37 & 7,8 \\
Reçete yazma konusunda yetersiz kalma & 12 & 2,5 \\
Sağlık personeliyle iletişim sorunu yaşama & 31 & 6,5 \\
Birinci basamakta çalışma & 15 & 3,2 \\
İşsiz kalma & 9 & 1,9 \\
Diğer & 4 & 0,8 \\
\hline
\end{tabular}

* Soruya birden fazla yanıt verilmiştir.

Tablo 4'te görüldüğ̈̈ gibi intörn hekimlerin mezun olduktan sonra mesleki uygulamaları yapmakla ilgili kayg1 sebeplerinde \% 25 ile ilk sırayı "acil hasta ile baş edememe kaygısı" almıştır. İkinci en çok işaretlenen kaygı sebebi \%19,2 ile 'mecburi hizmet' tir. Üçüncü olarak en çok işaretlenen kaygı sebebi ise \%15,8 ile 'hastayla tek başına baş edememe' kaygısıdır. Diğer kaygılar ise $\% 9,1$ ile 'hastalara yanlış tanı koyma'; \%8,0 ile 'klinik becerilerde yetersiz kalma' şeklindedir. Diğer bir kaygı nedeni \%6,5 ile 'sağlı personeliyle iletişism sorunu yaşama',
$\% 3,1$ ile 'birinci basamakta çalışmak', \%2,5 ile 'reçete yazma konusunda yetersiz kalmak', $\% 1,9$ ise 'işsiz kalmak' olarak işaretlenmiştir (Tablo 4).

Tablo 5'te hekimlik mesleğine yönelik tutum ve davranışlara önem verme derecelerine bakıldığında yığılmanın genel olarak sorulan beşli Likert ölçeğine göre ' 5 (çok)' seçeneğinde olduğu görülmektedir. Tabloda ortalama olarak en çok puanı 'temiz olma', 'insana sevgi sayg1', 'sır saklama' ve 'hastaya doğru teşhisi söyleme' maddeleri almıştır. 
Tablo 5. Çalışmaya katılan intörn hekimlerin önem verdikleri bazı tutum ve alışkanlıklar

\begin{tabular}{|c|c|c|c|c|c|c|}
\hline \multirow[b]{2}{*}{ Tutum ve Alışkanlıklar } & \multicolumn{5}{|c|}{ İşaretlenme yüzdesi } & \multirow[b]{2}{*}{$\begin{array}{c}\text { Madde } \\
\text { Ortalama }\end{array}$} \\
\hline & $\begin{array}{c}1 \\
\text { Hiç }\end{array}$ & 2 & 3 & 4 & $\begin{array}{c}5 \\
\text { Çok } \\
\end{array}$ & \\
\hline İnsana sevgi ve saygı & 0,6 & 3,9 & 6,7 & 23,5 & 65,4 & 4,5 \\
\hline Sir saklama & 2,2 & 1,7 & 8,9 & 26,8 & 60,3 & 4,4 \\
\hline Fedakarlık yapma & 2,8 & 5,6 & 24,0 & 33,5 & 34,1 & 3,9 \\
\hline Kendini yenileme & 1,1 & 2,2 & 14,5 & 35,8 & 46,4 & 4,2 \\
\hline Bilimsel şüpheciliğe sahip olma & 2,2 & 2,8 & 18,4 & 32,4 & 44,1 & 4,1 \\
\hline Meslekte paraya önem verme & 2,2 & 11,7 & 34,1 & 30,7 & 21,2 & 3,6 \\
\hline Hastaya doğru teşhisi söyleme & - & 1,3 & 6,9 & 39,6 & 52,2 & 4,4 \\
\hline Meslektaşların kararına saygılı olma & 0,6 & 1,9 & 20,8 & 39,0 & 37,7 & 4,1 \\
\hline Temiz olma & - & 1,1 & 6,2 & 24,2 & 68,5 & 4,6 \\
\hline Tıp uygulamalarında ekonomiye özen gösterme & 5,0 & 8,9 & 24,0 & 39,1 & 22,9 & 3,7 \\
\hline
\end{tabular}

Tablo 5 incelendiğinde hekimlerin önemli bir kısmının 'bilimsel şüpheciliğe sahip olma', 'kendini olma' maddelerinin de görece yüksek puanlandığı yenileme' ve 'meslektaşlarının kararlarına saygılı görülmektedir.

Tablo 6. Çalışmaya katılan intörn hekimlerin Ulusal Çekirdek Eğitim Programında yer alan temel hekimlik uygulamaların izleme durumlarının, yapma durumlarının ve yapabileceklerine dair inançlarının yüzdesi

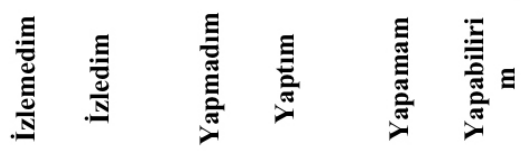

\begin{tabular}{lllllll}
\hline A) Öykü Alma & & & & & \\
1. Genel ve soruna yönelik öykü alabilme & 8,4 & 91,6 & 8,3 & 91,7 & 12,7 & 87,3 \\
2. Mental durumu değerlendirebilme & 9,6 & 90,4 & 13,0 & 87,0 & 16,4 & 83,6 \\
3. Psikiyatrik öykü alabilme & 10,8 & 89,2 & 20,8 & 79,2 & 21,3 & 78,7 \\
\hline B) Genel ve Soruna Yönelik Fizik Muayene & & & & & & \\
1. Adli olgu muayenesi & 37,6 & 62,4 & 68,3 & 31,7 & 55,8 & 44,2 \\
2. Antropometrik ölçümler & 12,7 & 87,3 & 16,9 & 83,1 & 14,9 & 85,1 \\
3. Baş-boyun ve KBB muayenesi & 8,4 & 91,6 & 13,6 & 86,4 & 14,0 & 86,0 \\
4. Batın muayenesi & 7,8 & 92,2 & 8,9 & 91,1 & 12,2 & 87,8 \\
5. Bilinç değerlendirmesi ve ruhsal durum muayenesi & 8,9 & 91,1 & 13,6 & 86,4 & 15,2 & 84,8 \\
6.a Cocuk muayenesi & 7,7 & 92,3 & 13,1 & 86,9 & 15,8 & 84,2 \\
6.b Yenidoğan muayenesi & 18,3 & 81,7 & 43,4 & 56,6 & 34,5 & 65,5 \\
7. Deri muayenesi & 15,4 & 84,6 & 27,5 & 72,5 & 20,7 & 79,3 \\
8. Digital rektal muayene & 13,7 & 86,3 & 48,8 & 51,2 & 28,7 & 71,3 \\
9. Gebe muayenesi & 28,6 & 71,4 & 61,8 & 38,2 & 53,7 & 46,3 \\
10. Genel bulgular ve vital bulguların değerlendirilmesi & 8,8 & 91,2 & 11,3 & 88,7 & 11,6 & 88,4 \\
11. Göz dibi muayenesi & 16,7 & 83,3 & 33,7 & 66,3 & 52,8 & 47,2 \\
12. Jinekolojik muayene & 22,4 & 77,6 & 59,1 & 40,9 & 50,9 & 49,1 \\
13. Kardiyovasküler sistem muayenesi & 9,6 & 90,4 & 11,9 & 88,1 & 13,5 & 86,5 \\
14. Kas-iskelet sistem muayenesi & 8,4 & 91,6 & 11,2 & 88,8 & 12,2 & 87,8 \\
15. Meme ve aksiller bölge muayenesi & 15,7 & 84,3 & 30,8 & 69,2 & 23,6 & 76,4 \\
16. Nörolojik muayene & 7,8 & 92,2 & 10,7 & 89,3 & 13,0 & 87,0 \\
17. Olay yeri incelemesi & 81,0 & 19,0 & 87,2 & 12,8 & 76,1 & 23,9
\end{tabular}


18. Ölü muayenesi

19. Solunum sistemi muayenesi

$65,3 \quad 34,7$

$89,7 \quad 10,3$

$63,6 \quad 36,4$

20. Ürolojik muayene

$\begin{array}{llllll}9,6 & 90,4 & 9,5 & 90,5 & 11,7 & 88,3\end{array}$

C) Kayit Tutma, Raporlama ve Bildirim

$\begin{array}{llllll}28,7 & 71,3 & 49,1 & 50,9 & 40,2 & 59,8\end{array}$

1. Adli rapor hazırlayabilme

2. Aydinlatma ve onam alabilme

3. Epikriz hazırlayabilme

4. Hasta dosyası hazırlayabilme

5. Hastaları uygun biçimde sevk edebilme

6. Ölüm belgesi düzenleyebilme

7. Raporlama ve bildirimi düzenleyebilme

8. Reçete düzenleyebilme

9. Tedaviyi red belgesi hazırlayabilme

\section{D) Laboratuvar Testleri ve İlgili Diğer İşlemler}

1. Biyolojik materyalle çalışma ilkelerini uygulayabilme

2.a Dekontaminasyon sağlayabilme

2.b Dezenfeksiyon sağlayabilme

2.c Sterilizasyon sağlayabilme

2.d Antisepsi sağlayabilme

3.a Dışkı yayması hazırlayabilme

3.b Dışkı yaymasında mikroskopik inceleme yapabilme

4. Direkt radyografileri okuma ve değerlendirebilme

5.a EKG çekebilme

5.b EKG değerlendirebilme

6. Gaitada gizli kan incelemesi yapabilme

7.a Glukometre ile kan şekeri ölçümü yapabilme

7.b Kan şekeri ölçüm sonucunu değerlendirebilme

8.a Kanama zamanı ölçümü yapabilme

8.b Kanama zamanı ölçüm sonucunu değerlendirebilme

9. Laboratuvar inceleme için istek formunu doldurabilme

10. Laboratuvar örneğini uygun koşullarda alabilme ve laboratuvara ulaştırabilme

11. Mikroskop kullanabilme

12.a Mikroskopik inceleme için boyalı-boyasız preparat hazırlayabilme

12.b Mikroskopikta preparat inceleyebilme

13.a Peak-flow metre kullanabilme

13.b Peak-flow metre sonucunu değerlendirebilme

14.a Periferik yayma yapabilme

14.b Periferik yayma değerlendirebilme

15. Su dezenfeksiyonu yapabilme

16. Su numunesi alabilme

17.a Sularda klor düzeyini belirleyebilme

17.b Sularda klor düzeyini değerlendirebilme

18. Tam idrar analizi (mikroskopik inceleme dahil) yapabilme

18.b Tam idrar analizi (mikroskopik inceleme dahil) değerlendirebilme

19. Tarama ve tanısal amaçlı inceleme sonuçlarını yorumlayabilme

\begin{tabular}{llllll}
53,9 & 46,1 & 75,9 & 24,1 & 62,3 & 37,1 \\
13,3 & 86,7 & 16,2 & 83,8 & 15,5 & 84,5 \\
18,9 & 81,1 & 22,7 & 77,3 & 22,2 & 77,8 \\
15,6 & 84,4 & 16,4 & 83,6 & 18,0 & 82,0 \\
50,0 & 50,0 & 69,3 & 30,7 & 52,1 & 47,9 \\
52,4 & 47,6 & 85,4 & 14,6 & 59,5 & 40,5 \\
60,7 & 39,3 & 76,2 & 23,8 & 58,9 & 41,1 \\
12,0 & 88,0 & 11,4 & 88,6 & 13,6 & 86,4 \\
25,6 & 74,4 & 28,4 & 71,6 & 26,4 & 73,6 \\
\hline
\end{tabular}

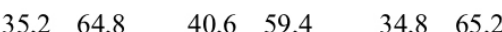

$\begin{array}{llllll}30,3 & 69,7 & 39,5 & 60,5 & 33,5 & 66,5\end{array}$

$\begin{array}{llllll}23,6 & 76,4 & 32,5 & 67,5 & 26,4 & 73,6\end{array}$

$\begin{array}{llllll}33,5 & 66,5 & 44,1 & 55,9 & 36,5 & 63,5\end{array}$

$\begin{array}{llllll}25,1 & 74,9 & 34,2 & 65,8 & 27,8 & 72,2\end{array}$

$\begin{array}{llllll}29,5 & 70,5 & 42,6 & 57,4 & 34,2 & 65,8\end{array}$

$\begin{array}{llllll}51,5 & 48,5 & 65,6 & 34,4 & 53,5 & 46,5\end{array}$

$\begin{array}{llllll}9,0 & 91,0 & 12,2 & 87,8 & 22,0 & 78,0\end{array}$

$\begin{array}{llllll}9,7 & 90,3 & 11,0 & 89,0 & 15,7 & 84,3\end{array}$

$\begin{array}{llllll}9,6 & 90,4 & 14,1 & 85,9 & 27,7 & 72,3\end{array}$

$\begin{array}{llllll}57,8 & 42,2 & 64,6 & 35,4 & 54,4 & 45,6\end{array}$

$\begin{array}{lllllll}10,3 & 89,7 & 11,6 & 88,4 & 12,5 & 87,5\end{array}$

$\begin{array}{llllll}10,3 & 89,7 & 11,0 & 89,0 & 13,8 & 86,2\end{array}$

$\begin{array}{llllll}46,3 & 53,7 & 53,4 & 46,6 & 46,9 & 53,1\end{array}$

$\begin{array}{lllllll}32,7 & 67,3 & 36,8 & 63,2 & 33,1 & 66,9\end{array}$

$\begin{array}{llllll}17,1 & 82,9 & 17,4 & 82,6 & 20,0 & 80,0\end{array}$

$\begin{array}{llllll}12,2 & 87,8 & 11,7 & 88,3 & 13,8 & 86,3\end{array}$

$\begin{array}{llllll}12,7 & 87,3 & 14,7 & 85,3 & 22,5 & 77,5\end{array}$

$\begin{array}{llllll}20,0 & 80,0 & 21,6 & 78,4 & 32,9 & 67,1\end{array}$

$\begin{array}{llllll}14,0 & 86,0 & 18,5 & 81,5 & 27,0 & 73,0\end{array}$

$\begin{array}{llllll}68,5 & 31,5 & 80,5 & 19,5 & 70,0 & 30,0\end{array}$

$\begin{array}{llllll}68,5 & 31,5 & 76,3 & 23,8 & 69,6 & 30,4\end{array}$

$\begin{array}{lllllll}20,1 & 79,9 & 31,5 & 68,5 & 32,7 & 67,3\end{array}$

$\begin{array}{llllll}24,1 & 75,9 & 38,5 & 61,5 & 43,8 & 56,3\end{array}$

$\begin{array}{llllll}69,3 & 30,7 & 78,9 & 21,1 & 66,9 & 33,1\end{array}$

$\begin{array}{llllll}57,8 & 42,2 & 78,3 & 21,7 & 58,8 & 41,3\end{array}$

$\begin{array}{llllll}59,0 & 41,0 & 82,0 & 18,0 & 61,9 & 38,1\end{array}$

$\begin{array}{llllll}57,8 & 42,2 & 80,2 & 19,8 & 62,1 & 37,9\end{array}$

$\begin{array}{llllll}50,0 & 50,0 & 58,4 & 41,6 & 55,3 & 44,7\end{array}$

$\begin{array}{llllll}34,1 & 65,9 & 40,6 & 59,4 & 39,6 & 60,4\end{array}$

$21,1 \quad 78,9 \quad 23,1 \quad 76,9 \quad 23,8 \quad 76,3$ 
20.a Transkütan bilüribin ölçebilme değerlendirebilme

20.b Transkütan bilüribin ölçümü değerlendirebilme

21.a Vaginal akıntı örneği incelemesi yapabilme (ürogenital enfeksiyon taraması. taze preparat hazırlama ve bakısı)

21.b Vaginal akıntı örneği değerlendirme

\section{E) Girişimsel ve girişimsel olmayan uygulamalar}

1. Acil psikiyatrik hastanın stabilizasyonunu yapabilme

2. Adli olguların ayırt edilebilmesi / yönetilebilmesi

3. "Airway" uygulama

4. Akılcı ilaç kullanımı

5. Atel hazırlayabilme ve uygulayabilme

6. Bandaj turnike uygulayabilme

7. Burna ön tampon koyabilme ve alabilme

8. Çocuklarda büyüme ve gelişmeyi izleyebilme (persentil eğrileri, tanner derecelendirmesi)

9. Damar yolu açabilme

10. Defibrilasyon uygulayabilme

11. Delil tanıyabilme/ koruma/ nakil

12. Deri ve yumuşak doku apsesi açabilme

13. Dış kanamayı durduracak / sınırlayacak önlemleri alabilme

14. Doğum sonrası anne bakımını yapabilme

15. Doğum sonrası bebek bakımı yapabilme

16. El yıkama

17. Entübasyon yapabilme

18. Epizyotomi açılabilme ve dikebilme

19. Galveston oryantasyon skalası

20. Gebe ve loğusa izlemi yapabilme

21. Glasgow koma skalasının değerlendirilebilme

22. Hastadan biyolojik örnek alabilme

23. Hastalık / travma şiddet skorlamasını değerlendirilebilme

24. Hastanın uygun olarak taşınmasını sağlayabilme

25 . Hastaya koma pozisyonu verebilme

26. Hava yolundaki yabancı cismi uygun manevra ile çıkarabilme

27. Hukuki ehliyeti belirleyebilme

28.a IM enjeksiyon yapabilme

28.b IV enjeksiyon yapabilme

28.c SC enjeksiyon yapabilme

28.d ID enjeksiyon yapabilme

29. İdrar sondası takabilme

30. İleri yaşam desteği sağlayabilme

31. İntihar riskini değerlendirme

32. İntihara müdahale edebilme

33. Kan basıncı ölçümü yapabilme

34. Kan transfüzyonu yapabilme

35. Kapiller kan örneği alabilme

36. Kene çıkartabilme

37. Kötü haber verebilme
$78,9 \quad 21,1 \quad 79,4 \quad 20,6$

$\begin{array}{llll}75,9 & 24,1 & 76,3 & 23,8\end{array}$

$\begin{array}{llll}70,5 & 29,5 & 78,3 & 21,7\end{array}$

$69,8 \quad 30,2$

$68,4 \quad 31,6$

$67,3 \quad 32,7$

\begin{tabular}{llllll}
68,3 & 31,7 & 76,4 & 23,6 & 63,9 & 36,1 \\
\hline
\end{tabular}

$\begin{array}{llllll}38,6 & 61,4 & 65,8 & 34,2 & 54,4 & 45,6 \\ 31,5 & 68,5 & 47,8 & 52,2 & 41,5 & 58,5 \\ 13,3 & 86,7 & 32,5 & 67,5 & 24,5 & 75,5 \\ 15,2 & 84,8 & 21,3 & 78,8 & 17,7 & 82,3 \\ 17,0 & 83,0 & 27,2 & 72,8 & 27,2 & 72,8 \\ 20,7 & 79,3 & 27,2 & 72,8 & 25,2 & 74,8 \\ 29,7 & 70,3 & 49,7 & 50,3 & 30,8 & 69,2 \\ 15,2 & 84,8 & 21,6 & 78,4 & 17,5 & 82,5\end{array}$

$\begin{array}{llllll}12,1 & 87,9 & 12,5 & 87,5 & 12,0 & 88,0\end{array}$

$\begin{array}{llll}19,3 & 80,7 & 58,2 & 41,8\end{array}$

$29,7 \quad 70,3$

$71,8 \quad 28,2$

$80,4 \quad 19,6$

$67,7 \quad 32,3$

$\begin{array}{llll}47,9 & 52,1 & 70,6 & 29,4\end{array}$

$50,9 \quad 49,1$

$\begin{array}{llllll}26,1 & 73,9 & 42,2 & 57,8 & 23,4 & 76,6\end{array}$

$\begin{array}{llllll}57,3 & 42,7 & 74,5 & 25,5 & 57,9 & 42,1\end{array}$

$\begin{array}{llllll}50,0 & 50,0 & 71,4 & 28,6 & 55,3 & 44,7\end{array}$

$\begin{array}{lllllll}9,1 & 90,9 & 11,7 & 88,3 & 13,2 & 86,8\end{array}$

$\begin{array}{llllll}10,9 & 89,1 & 32,7 & 67,3 & 31,4 & 68,6\end{array}$

$\begin{array}{llllll}39,8 & 60,2 & 82,4 & 17,6 & 64,8 & 35,2\end{array}$

$\begin{array}{llllll}76,9 & 23,1 & 79,7 & 20,3 & 73,5 & 26,5\end{array}$

$\begin{array}{llllll}48,5 & 51,5 & 70,9 & 29,1 & 59,0 & 41,0\end{array}$

$\begin{array}{llllll}15,9 & 84,1 & 24,5 & 75,5 & 19,5 & 80,5\end{array}$

$\begin{array}{llllll}22,0 & 78,0 & 25,9 & 74,1 & 26,4 & 73,6\end{array}$

$\begin{array}{llllll}47,6 & 52,4 & 63,8 & 36,3 & 56,6 & 43,4\end{array}$

$\begin{array}{llllll}20,6 & 79,4 & 35,0 & 65,0 & 24,4 & 75,6\end{array}$

$58,2 \quad 41,8 \quad 65,6 \quad 34,4 \quad 60,8 \quad 39,2$

$\begin{array}{llllll}51,5 & 48,5 & 70,2 & 29,8 & 47,5 & 52,5\end{array}$

$\begin{array}{llllll}68,9 & 31,1 & 85,6 & 14,4 & 72,5 & 27,5\end{array}$

$\begin{array}{llllll}15,0 & 85,0 & 10,7 & 89,3 & 11,5 & 88,5\end{array}$

$\begin{array}{llllll}14,3 & 85,7 & 12,6 & 87,4 & 13,5 & 86,5\end{array}$

$\begin{array}{llllll}16,2 & 83,8 & 17,5 & 82,5 & 16,9 & 83,1\end{array}$

$\begin{array}{llllll}22,5 & 77,5 & 28,9 & 71,1 & 24,8 & 75,2\end{array}$

$\begin{array}{llllll}11,1 & 88,9 & 10,7 & 89,3 & 12,8 & 87,2\end{array}$

$\begin{array}{llllll}15,4 & 84,6 & 34,4 & 65,6 & 29,1 & 70,9\end{array}$

$\begin{array}{llllll}43,2 & 56,8 & 61,0 & 39,0 & 50,0 & 50,0\end{array}$

$\begin{array}{llllll}62,7 & 37,3 & 75,2 & 24,8 & 65,6 & 34,4\end{array}$

$\begin{array}{llllll}12,3 & 87,7 & 12,4 & 87,6 & 12,7 & 87,3\end{array}$

$\begin{array}{llllll}24,4 & 75,6 & 61,0 & 39,0 & 39,9 & 60,1\end{array}$

$\begin{array}{llllll}28,8 & 71,2 & 31,3 & 68,8 & 26,4 & 73,6\end{array}$

$\begin{array}{llllll}70,1 & 29,9 & 79,9 & 20,1 & 60,5 & 39,5\end{array}$

\begin{tabular}{llllll}
20,1 & 79,9 & 44,7 & 55,3 & 23,4 & 76,6 \\
\hline
\end{tabular}

38. Kültür için örnek alabilme

$\begin{array}{llllll}11,7 & 88,3 & 11,9 & 88,1 & 11,5 & 88,5\end{array}$


39. Lavman yapabilme

40. Lomber ponksiyon yapabilme

41. Mide yıkayabilme

42. Mini mental durum muayenesi

43. Nazogastrik sonda uygulayabilme

44. Normal spontan doğum yaptırabilme

45. Oksijen ve nebul-inhaler tedavisi uygulayabilme

46.a Oral ilaç uygulamaları yapabilme

46.b Rektal ilaç uygulamaları yapabilme

46.c Vajinal ilaç uygulamaları yapabilme

46.d Topikal ilaç uygulamaları yapabilme

47. Parasentez yapabilme

48. Perikardiyosentez yapabilme

49. Plevral ponksiyon yapabilme

50. PPD testi uygulayabilme

51. Puls oksimetre uygulayabilme ve değerlendirebilme

52. Rıza ehliyetini belirleyebilme

53. Rinne-Weber ve Schwabach testleri uygulayabilme

54. Servikal collar (boyunluk) uygulayabilme

55. Soğuk zincire uygun koruma ve taşıma sağlayabilme

56. Solunum fonksiyon testlerini değerlendirebilme

57. Solunum havasında alkol ölçümü yapabilme

58.a Soyağacını çıkarabilme

58.b Gerektiğinde genetik danışmanlığa yönlendirebilme

59. Suprapubik mesane ponksiyonu yapabilme

60. Temel yaşam desteği sağlayabilme

61. Tıp uygulamalarında etik sorunları çözebilme

62. Topuk kanı alabilme

63. Travma sonrası kopan uzvun uygun olarak taşınmasını sağlayabilme

64. Uygulanacak ilaçları doğru şekilde hazırlayabilme

65. Vajinal ve servikal örnek alabilme

66. Yara-yanık bakımı yapabilme

67. Yenidoğan canlandırması

68. Yüzeyel sütür atabilme ve alabilme

\begin{tabular}{llllll}
41,7 & 58,3 & 61,6 & 38,4 & 39,9 & 60,1 \\
18,3 & 81,7 & 64,6 & 34,8 & 48,4 & 51,6 \\
39,6 & 60,4 & 70,3 & 29,7 & 48,1 & 51,9 \\
16,0 & 84,0 & 31,9 & 68,1 & 24,2 & 75,8 \\
11,0 & 89,0 & 35,2 & 64,8 & 19,2 & 80,8 \\
35,0 & 65,0 & 76,6 & 23,4 & 56,6 & 43,4 \\
14,2 & 85,8 & 20,6 & 79,4 & 19,1 & 80,9 \\
11,1 & 88,9 & 12,5 & 87,5 & 12,7 & 87,3 \\
50,0 & 50,0 & 62,3 & 37,7 & 42,7 & 57,3 \\
66,0 & 34,0 & 71,1 & 28,9 & 51,6 & 48,4 \\
17,9 & 82,1 & 26,9 & 73,1 & 18,5 & 81,5 \\
26,1 & 73,9 & 69,6 & 30,4 & 52,2 & 47,8 \\
64,8 & 35,2 & 86,2 & 13,8 & 76,7 & 23,3 \\
62,7 & 37,3 & 85,1 & 14,9 & 73,3 & 26,7 \\
14,6 & 85,4 & 29,9 & 70,1 & 18,0 & 82,0 \\
13,4 & 86,6 & 14,4 & 85,6 & 15,3 & 84,7 \\
59,1 & 40,9 & 75,6 & 24,4 & 60,0 & 40,0 \\
27,3 & 72,7 & 36,3 & 63,8 & 30,2 & 69,8 \\
32,1 & 67,9 & 48,1 & 51,3 & 30,6 & 69,4 \\
35,0 & 65,0 & 59,6 & 40,4 & 40,4 & 59,6 \\
18,3 & 81,7 & 36,3 & 63,8 & 24,8 & 75,2 \\
73,9 & 25,5 & 80,7 & 19,3 & 63,9 & 36,1 \\
24,4 & 75,6 & 38,1 & 61,9 & 22,0 & 78,0 \\
23,2 & 76,8 & 38,5 & 61,5 & 22,6 & 77,4 \\
61,8 & 38,2 & 78,3 & 21,7 & 61,6 & 38,4 \\
18,2 & 81,8 & 28,8 & 71,3 & 27,7 & 72,3 \\
30,5 & 69,5 & 51,6 & 48,4 & 37,5 & 62,5 \\
33,1 & 66,9 & 46,9 & 53,1 & 25,6 & 74,4 \\
59,8 & 40,2 & 75,0 & 25,0 & 44,4 & 55,6 \\
& & & & & \\
26,2 & 73,8 & 34,6 & 65,4 & 29,1 & 70,9 \\
37,8 & 62,2 & 62,3 & 37,7 & 43,8 & 56,3 \\
20,6 & 79,4 & 25,5 & 74,5 & 23,3 & 76,7 \\
50,9 & 49,1 & 75,8 & 24,2 & 63,9 & 36,1 \\
14,0 & 86,0 & 24,1 & 75,9 & 21,3 & 78,8 \\
\hline & & & & &
\end{tabular}

F. Koruyucu Hekimlik ve Toplum Hekimliği Uygulamaları

1. Acil yardımların organizasyonunu yapabilme

2. Aile danışmanlığı verebilme

3. Aile planlaması danışmanlığı yapabilme

4. Bağışıklama hizmetlerini yürütebilme

5. Doğru emzirme yöntemlerini öğretebilme

6. Esnaf ve işyeri denetimi yapabilme

$\begin{array}{llll}36,2 & 63,8 & 52,8 & 47,2\end{array}$

$\begin{array}{llll}26,4 & 73,6 & 49,7 & 50,3\end{array}$

$39,6 \quad 60,4$

$35,4 \quad 64,6$

$64,2 \quad 35,8$

$28,9 \quad 71,1$

$\begin{array}{llll}29,9 & 70,1 & 50,6 & 49,4\end{array}$

$32,9 \quad 67,1$

$\begin{array}{llllll}33,5 & 66,5 & 57,9 & 42,1 & 29,2 & 70,8\end{array}$

$\begin{array}{llll}77,4 & 22,6 & 80,6 & 19,4\end{array}$

\begin{tabular}{ll}
67,3 & 32,7 \\
\hline
\end{tabular}

8. Kontrasepsiyon yöntemlerini doğru uygulayabilme ve
kullanıcıları izleyebilme

$\begin{array}{llllll}42,1 & 57,9 & 60,9 & 39,1 & 39,1 & 60,9\end{array}$

9. Olağan dıșı durumlarda sağlık hizmeti sunabilme

$\begin{array}{llll}60,4 & 39,6 & 70,6 & 29,4\end{array}$

$47,8 \quad 52,2$

10. Periyodik muayene, kontrol ( Kardiyak risk hesaplama,

$30,2 \quad 69,8$

50,3

49,7

$29,4 \quad 70,6$ adölesan danışmanlığı, tütün danışmanlığı, kanser taraması $\mathrm{vb)}$

11. Sağlık hizmeti ilişkili enfeksiyonları engelleyici önlemleri alabilme $\begin{array}{llllll}31,7 & 68,3 & 47,8 & 52,2 & 29,4 & 70,6\end{array}$ 
12. Toplu yașam alanlarında enfeksiyonları engelleyici önlemleri alma

13. Topluma sağlık eğitimi verebilme

14. Toplumda bulaşıcı hastalıklarla mücadele edebilme

15. Toplumda sağlıkla ilgili sorunları epidemiyolojik yöntemler kullanarak saptayabilme ve çözüm yollarını ortaya koyabilme
Çalışmaya katılan intörn hekimlerin UÇEP'te yer alan temel hekimlik uygulamalarını izleme, yapma durumlarının ve yapabileceklerine dair inançlarına ait bulgular tablo 6'da yer almaktadır. Dikkat çeken özellikteki bulgular ise aşağıda başlıklar halinde paylaşılmıștır.

\section{A) Öykü Alma}

İntörn hekimlerin \%87,3'ü hekimlik mesleğinin temel aşamalarından olan 'genel öykü alma' olan "genel öykü alma"yı ve \%87,6's1 “mental durum muayenesi”ni yapabildiğini belirtmişlerdir. \%87,6's1 'mental durum muayenesi’ni yapabildiğini belirtmişlerdir. İntörn hekimlerin \%21,3'ü 'psikiyatrik hasta öyküsünü alma' konusunda kendilerini yeterli görmemektedir.

\section{B) Genel ve Soruna Yönelik Fizik Muayene}

Genel ve soruna yönelik fizik muayenelerin birçoğunda (baş boyun, KBB, solunum sistemi, kas iskelet) kendilerini beceriyi yapma konusunda $\% 80$ ve üzeri yeterli görmüşlerdir. Fakat 'adli olgu', 'gebe muayenesi', 'gözdibi muayenesi', 'yenidoğan muayenesi' dahil olmak üzere bazı temel becerilerde kendilerini yeterli olarak görmemişlerdir.

\section{C) Kayit Tutma Raporlama ve Bildirim}

Kayıt tutma ve raporlama başlığında yer alan dokuz beceriden "Alanında reçete düzenleyebilme 'aydinlatma ve onam alabilme', 'hasta dosyası hazırlayabilme' becerileri dışındaki becerilerde "yapamam" şeklinde belirten intörn hekimler \%30 ve üzerindedir.

\section{D) Laboratuvar Testleri ve İlgili Diğer İşsemler}

Laboratuvar testleri ile ilgili birçok işlemi hem izleme hem yapma yüzdeleri birbirleriyle orantılı ve

$\begin{array}{rrrrrr}41,1 & 58,9 & 57,5 & 42,5 & 33,5 & 66,5 \\ & & & & & \\ 31,7 & 68,3 & 51,3 & 48,8 & 27,3 & 72,7 \\ 37,8 & 62,2 & 58,1 & 41,9 & 34,2 & 65,8 \\ 37,2 & 62,8 & 57,9 & 42,1 & 37,3 & 62,7\end{array}$

düşüktür. Bununla ilişkili olarak yapabilme yüzdesi de düşük olarak bulunmuştur. 'Direkt radyografileri okuma ve değerlendirebilme', 'EKG çekebilme', 'EKG değerlendirebilme', 'mikroskop kullanabilme', 'mikroskopik inceleme için boyalı-boyasız preparat hazırlayabilme', 'mikroskopta preparat inceleyebilme' becerilerinde izleme ve yapma yaklaşık olarak $\% 80$ ve üzeridir.

\section{E) Girişimsel ve girişimsel olmayan uygulamalar}

Acil psikiyatrik hastanın stabilizasyonu becerisi için katılımcıların yarıdan fazlası izlediğini belirtse de daha önce uygulamış katılımcıların yüzdesi düşüktür. 'Airway uygulama', 'akılcı ilaç kullanımı', 'atel hazırlama ve uygulama', 'bandaj ve turnike uygulama', 'çocuklarda büyüme ve gelişmeyi izleyebilme', 'damaryolu açabilme' gibi hastane içerisinde daha sık karşılaşılan durumlarla ilgili becerileri hem izleme hem yapma hem de ileride yapabilme için belirtilen yüzdelerin çok daha yüksek olduğunu görülmektedir. 'Defibrilasyon uygulama' ve 'burna ön tampon uygulama' becerilerinde izleme oranları yüksek olmasına rağmen yapma oranlarının daha düşük olması ile uyumlu olarak ileride yapabilme konusunda katılımcıların kendine güvenlerinin de sık yapılan uygulamalara oranla daha düşük olduğu görülmektedir.

'Delil tanıabilme/koruma/nakil' becerisi hem izlenmediği hem de yapılmadığı için yapabileceklerini düşünenlerin yüzdesinin çok düşük olduğu görülmektedir. 'Deri ve yumuşak doku apsesi açabilme' becerisini yapabileceğini düşünen öğrenci yüzdesinin de düşük olduğu görülmektedir. Öğrencilerin \%40-50'si ‘doğum sonrası anne ve bakımı', 'gebe ve loğusa izlemi' becerilerini izlediğini belirtirken, \%20-30'u yaptığını, 
\%40-50'si ise ileride yapabileceğini belirtmiştir. 'Galveston oryantasyon skalası', 'hastalık/travma şiddet skorlamasını değerlendirebilme', 'hastaya koma pozisyonu verme', 'havayolundaki yabanc1 cismi uygun manevra ile çıkarabilme' ve 'hukuki ehliyeti belirleyebilme' becerilerinde hem izleme hem yapma hem de yapabilme yüzdelerinin birbirleriyle ilişkili olacak şekilde düşük olduğu görülmüştür. 'İleri yaşam desteği sağlayabilme' becerisinin bu beceriler kadar yüksek olmasa da yine büyük bir orandaki katılımcı tarafından izlendiği ve yapıldı̆̆ görülmektedir. Katılımcıların yaklaşık \%50'si 'yenidoğan canlandırması'nı izlediğini belirtmesine rağmen, \%63'ü yapamayacağını belirtilmiştir.

\section{F. Koruyucu Hekimlik ve Toplum Hekimliği Uygulamaları}

'Esnaf ve işyeri denetimi yapabilme', 'olağan dış1 durumlarda sağlık hizmeti sunabilme' becerilerinde izleme ve yapma yüzdeleri çok düşüktür. Bunlar dışında koruyucu hekimlik ve toplum hekimliği uygulamaları başlığı altındaki becerilerin kalanları için katılımcılar kendilerini $\% 60$ ve üzerinde yeterli görmektedir.

\section{TARTIŞMA}

Çalışmaya katılan intörn hekimlerin, tıp fakültesini tercih etme nedeni olarak \%25'i topluma yararl 1 olabilmek, \%21,2'si iş garantisi, \%20,1'i mesleki kariyer, \%18,2'si sosyal statü ve prestij ve \%14'ü aile isteği yanıtlarını vermiştir. Alper ve arkadaşları (2004) tarafindan yapılan bir çalışmada araştırmaya katılanların \%33'ü insanları sevdiklerini ve onlara yardım etmeyi istedikleri için, \%17'si garanti bir meslek olduğu için tıp mesleğini seçtiklerini belirtmiştir (22). Oransal olarak az da olsa ÖSYM puanı, aile gibi farklı nedenlerin de tercihte etkili olduğu gösterilmiştir. Hacettepe Üniversitesi Halk Sağlığ1 Anabilim Dalı öğrencilerinin (2017) intörn hekimlerle yaptığı çalışmada ise katılımcıların \%51'i insanlara yardım etmek istediği için tercih ettiğini belirtirken, \%14'ü ise aile baskısıyla tercih ettiğini belirtmiştir (21). Mevcut araştırmamızda ve yapılmış olan diğer çalışmalarda insanlara yardım etme isteğinin ve insan sevgisinin, tıp fakültesi tercih nedenlerinin başında geldiği görülmektedir. Öğrencilerin uzun, yorucu ve zor bir eğitim olan tıp eğitimini, hekimlik mesleğini tanıyarak, severek isteyerek seçmiş olmaları, eğitim ve çalışma yaşantılarında başarı, mutluluk ve mesleki tatmin için gereklidir.

Öğrencilerin mezuniyet sonrası kariyer düşünceleri ile tıpta uzmanlık yapma isteğine verdikleri yanıtlar uyumlu görünmekle birlikte, uzmanlık eğitimi alma isteklerinin yüksek olduğu göze çarpmaktadır. Öğrencilerin sadece \%2,8'i pratisyen hekimlik yapmak istediğini belirtirken, \%87,6's1 yurtiçinde ve $\% 5,1$ 'i ise yurt dişında uzmanlık eğitimi almak istediğini belirtmiştir. Türkiye'de yapılmış farklı çalışmalarda uzmanlık eğitimi almak isteyenlerin yüzdesi \%84 ile \%98,4 arasında bildirilmiştir (21,2328). Farklı yıllarda, farklı fakültelerde yapılan bu çalışmalarda öğrencilerin çok büyük bir yüzdesinin uzmanlık eğitimi almak istedikleri, pratisyen hekimliği tercih etmedikleri izlenmektedir. Bu durum ülkenin sağlık problemlerinin çözümünde anahtar rol oynayan pratisyen hekimliğe değer atfedilmediğini, tıp fakültesi öğrencilerinin kendilerini uzmanlığa odakladığı şeklinde yorumlanabilir. Hacettepe Üniversitesinde yapılan farklı bir çalışmanın bulguları da bunu desteklemektedir. Çalışmada intörnlerin \%43'ünün 'uzman olmaya' önemli değer atfettiği bildirilmiştir (27). Bu alanda yapılan çalışmalarda, uzman hekimliğin tercih edilmesinin en önemli nedenleri olarak; parasal tatmin $\% 42,4$, mesleki doyum $\% 38$, sosyal statü $\% 25$, bir alana özel ilgi duyma $\% 11,4$ ve akademik kariyer yapma isteği $\% 9,8$ bildirilmektedir (18). Birçok fakültenin misyon ve vizyonunda birinci basamak için donanımlı hekimler yetiştirmek olduğu vurgulansa da ülkemizdeki tıp eğitimi, planlanan ve uygulanan sağlık sisteminin yönlendirdiği amaç, uzmanlığı kazanmak olan öğrenciler yetiştirmektir (29-31). Verilen bu aşırı önemin sonucunda tıp öğrencilerinde genel tıbbi konularda yetersizlik duygusu oluşabilmekte, pratisyen hekimlik yapma hususunda güven eksikliği gelişebilmektedir (31). Öğretim elemanlarının, rol modellerin aşırı uzmanlanmış kişiler olduğu, hastaların özellikli hastalar olduğu ve birinci basamağı temsil 
etmediği bir üçüncü basamak hastanede eğitim alan, öğrencilik sürecinde birinci basamak kurumları ve burada görev yapan hekimleri sınırlı olarak gözleme şansına sahip olan tıp öğrencilerinin uzmanlığa bu kadar değer atfetmeleri beklendiktir.

Öğrencilerin çok büyük kısmı TUS dershanesine gitmektedir. Daha önceki bir çalışmada intörnlerin \%90'1 TUS dershanesine gitmek istediğini belirtmiştir (27). HÜ Halk Sağlığı Anabilim Dalı (2017) öğrencilerinin yürüttüğü çalışmanın da bulguları intörn hekimlerin \%82,7'sinin zamanlarının bir kısmını uzmanlık sınavına ayırdıklarını göstermiştir (21). Bu durum uzman hekim olma arzusundaki intörn hekimlerin ülkemizde uygulanan tıpta uzmanlık sınav sistemi karşısında dershaneye devam etme durumu arasında güçlü bir ilişki olduğu, sınav sisteminin yapısından ötürü bir dershane desteği almanın önemli olduğu görüşünü taşıdıklarını yansıtmaktadır. Uzmanlığa geçişte kademeli sınavların uygulandığı Amerika Birleşik Devletleri'nde de, öğrencilerin ticari kurslara önemli miktarda zaman ve para ayırdığı bildirilmektedir $(32,33)$.

Çalışmada intörnlerin makale okuma yüzdeleri incelendiğinde \%70’ten fazlasının hiç makale okumadığg görülmüştür. Tıp gibi literatürün çok hızlı güncellendiği, bilgi yarı ömrünün oldukça kısaldığ1 bir alanda intörn hekimlerin makale okumamaları düşündürücüdür.

Hekim adaylarının 1/3'ünün hekimlik uygulamasını başarıyla yapacağına dair özgüven düzeyinin az ya da kısmen olduğu bulunmuştur ve bunun nedenleri irdelenmeye değerdir. Bu durum eğitim programının sunuluşu ve bundan yararlanma durumu, üniversite hastanesinde görülen karmaşık vakaların çokluğu ya da öz değerlendirmede yansız olamama gibi birçok etkenden kaynaklanıyor olabilir. Ayrıca katılımcıların yaklaşık dörtte biri hekimlik mesleki uygulamalarını yapmak ile ilgili kaygılar taşımaktadır. Sağlık alanı öğrencilerinin diğer fakültelerden farklı bir süreci vardır. Öğretim süreçleri boyunca fiziken ve ruhen acı çeken hasta ve endişe içinde olan hasta yakınları ile karşıllaşan tıp fakültesi öğrencilerinin mesleki anksiyete ve kaygılarının fazla olduğu ifade edilmektedir (34). Özgüven eksikliğine neden olan faktörlerin kaygıya da yol açması beklenebilir. Çalışmamızda intörn hekimlerin en çok kaygılarının ise "acil hastayla baş edememe" olduğu görülmüştür. Yalçınoğlu ve arkadaşlarının (2012) intörn hekimlerle yaptığı bir çalışmada da katılımcıların büyük bir çoğunluğu acil hastaya yaklaşım konusunda kaygı duyduğunu belirtmiştir (35). Benzer şekilde Mayda ve arkadaşları (2014) tarafindan yapılan bir çalışmada öğrencilerin mezun olduktan sonra çalışacakları kurumlardan en az kaygı yaratanın aile hekimliği, en fazla kaygı oluşturanın ise devlet hastanesi acili olduğu belirtilmiştir (36). Birinci basamakta çalışan bir hekimin günlük hayatında en çok kullanması gereken becerilerden biri acil hastayı yönetebilmedir. Ancak tıp fakültesinde kuramsal ve uygulamalı programda önemli acillere sik s1k değinilmesine rağmen gerçek bir acil hastası ile karşılaşılması intörn hekimlik dönemini bulmaktadır. Klinik eğitimde hekim adayı çoklukla acil hastasının ameliyat sonrası dönemini ya da tedavi sonrası ayaktan kontrolünü görebilmektedir. Birçok staj içerisinde acil konuları önemsenerek anlatılsa ve tekrarlansa da pratik eğitim uygulamalarının yetersizliği kaygıya yol açmış olabilir. Acil hastaları ölüm ve kalım arasında hekimin hızlı ve doğru ayırıcı tanısıyla en kısa sürede müdahale ya da sevk gerektiren hastalar olduklarından tıp fakültesi eğitiminde her branşın kendi acillerini anlatmasının yanı sıra intörnlük yılından önce bütüncül yaklaşımı önceleyen acil eğitimlerinin ya da disiplinlerin acil hasta için yaptıkları danışmanlık ve müdahalelerin programa eklenmesi ve bu stajda hasta güvenliğini de göz önünde bulundurarak simülasyon gibi yöntemlerle eğitim programları düzenlenmesi ve öğrencilerin acil serviste öğrendiklerini gerçek yaşama transfer etmesi sağlanabilir. Kaygı nedenlerinden biri de mecburi hizmet olmuştur. Mecburi hizmette yeni mezun olmuş hekim eğitim gördüğü büyük bir kentten daha önce eğitim sürecinde deneyimleme imkanının olmadığı, hiç bulunmadığı küçük bir kente gönderilebilmekte ve alışmadığı bir iklim, bölge ve kültür ile karşılaşabilmektedir. Üstelik bazı durumlarda tek doktor olarak görev yapabilmekte ve sağlık hizmetlerine ek olarak bulunduğu kurumun yöneticiliğini üstlenebilmektedir. Mecburi hizmetin 
yarattığ1 bu belirsizlik durumu kaygıları artırıyor olabilir. Bir diğer önemli kaygı nedeni ise hastayla tek başına baş edememedir. Staj ve intörn hekimlik yılında kendinden daha tecrübeli doktorların rehberliğinde hasta yönetim sürecine tanık olan hekim adayı için hasta ile tek başına kalarak hekim sorumluluğunu tamamıyla üstleniyor olmanın kaygı vermesi doğaldır. Hekim adayının bu kaygıyı hekimhasta ilişkisinin dinamiklerini yönetmeyi, doğru ve güncel bilgiye ulaşmayı öğrenmesi, kademeli olarak mesleki uygulamalarda bağımsız çalışmalar yapması desteklenerek aşması sağlanabilir. Diğer kaygılar "hastalara yanlış tanı koyma", "klinik becerilerde yetersiz kalma" şeklindedir. Yeniçeri ve arkadaşları (2007) tarafindan yapılan bir çalışmada öğrencilerin birinci basamakta genel pratisyen olarak çalışmak ve tıbbi konularda yetersizlik ile ilgili kaygıları olduğu bulunmuştur (37). Tip fakültesi eğitimi boyunca onlarca disiplinin eleğinden geçen hekim adayı binlerce hastalık ismi duymakta, tıp bilgisinin çokluğu ve kendi zaman ve hafızasının sınırlarınca bu bilgileri öğrenmeye çalışmaktadır. Ancak tek bir hekimin tıbbın bütün içeriğine hakim olmasının olanaklı olamayacağı açıktır. $\mathrm{Bu}$ nedenle tıpta alt disiplinler oluşmuştur. Tıp fakültesi eğitiminin amacı her hastalığa tanı koyup tedavisini yürüten hekim yetiştirmek değil; iyi ayırıcı tanı yapabilen ve birinci basamakta yönetilmesi gereken hastaları iyi tanıyıp onların teşhis ve tedavisini yapabilen kendi bilgi, yetki ve sınırlarını aşan hastaları ise doğru birimlere danışabilen ve yönlendirebilen hekim yetiştirmektir. Tıp fakültesi eğitiminde birçok zaman bu temel amacin unutularak hekim adayına ayrıntılı ve uzmanlık, hatta yan dal uzmanlığı düzeyinde bilgi yüklemesi yapılmaya çalışılmaktadır. Tüm branşların bu temel amacı göz önüne alarak uygun hedefler koymaları ve hedefler doğrultusunda programlarını şekillendirmeleri öğrencilerde bu kaygıyı azaltacak aynı zamanda daha özgüvenli hekimlerin yetişmesini sağlayacaktır. Geleceğin hekimlerinin sağlık personeliyle iletişim sorunu yaşama konusunda da kaygısı olduğu görülmüştür. Mesleklerarası işbirliği, iletişim görev yetki ve sorumluluklar temalarında uygulamalı eğitim etkinlikleri düzenlenmesi ve eğitim sürecinin başından itibaren sağlık alanı öğrencileri arasında temasın kurulması bu kaygının azaltılmasına yardımcı olabilir.

Hekimlik mesleğine yönelik tutum ve davranışlara önem verme dereceleri incelendiğinde ortalama olarak en çok puanı temiz olma, insana sevgi saygı, sır saklama ve hastaya doğru teşhisi söyleme maddeleri almıştır. Bu maddelerin yüksek puan alması yüz güldürücüdür çünkü her biri tıp mesleği değerlerinin temel taşlarını oluşturmaktadır. Ancak bu tutuma tüm öğrencilerin sahip olması programların hedefi olduğundan bu maddelere 5'ten daha az önem verilmesine sebep olabilecek faktörler incelenmelidir.

Dikkat çeken bir diğer husus \%51,9 katılımcının meslekte paraya oldukça önem verdiğini belirtmesidir. 1991 y1lındaki TBMM raporunda ise araştırmaya katılanların \%34'ü meslekte paraya önem verdiğini belirtmiştir (15). Mesleğin zorluğu ve emeğin çokluğu dikkate alındığında iyi bir hayat beklentisine sahip olmak anlaşılabilir olsa da bu mesleki ilke ve değerlerin önüne geçebilecek derecede olmaması gerektiği düşünülmektedir. $\mathrm{Bu}$ bağlamda yıllar içindeki artış dikkat çekici ve incelemeye değerdir. "Tıp uygulamalarında ekonomiye özen gösterme" maddesinin ortalaması diğerlerine nispeten düşük ortalamada bulunmuştur. Bu önermeye verilen yanıtlar sağlığın ve yaşamın değer biçilemez önceliğinden kaynaklanabileceği gibi, günümüzde hekimlerin kendilerine dava açılması kaygısıyla adeta kanıt toplarmış gibi gereğinden fazla tetkik istemesinden de kaynaklanmış olabilir. Daha ileri araştırmalar ile gerekçeler incelenebilir. Çalışmamızda intörn hekimlerin bilimsel şüpheciliğe, kendini yenilemeye ve meslektaşlarının kararlarına saygılı olmaya önem verdikleri gözlenmiştir. Hekimlik mesleki tutum ve değerlerinin tıp fakültesi yıllarında öğrencilere en iyi şekilde kazandırılacak şekilde programların desteklenmesi önemlidir.

Çalışmada intörnhekimlerin UÇEP'teyeralan hekimlik becerilerine ilişkin yaptıkları değerlendirmeler aşağıda başlıklar halinde tartışılmıştır.

\section{Öykü Alma ve Fizik Muayene}

Hekimlikte öykü alma ve fizik muayene tanı koymak 
için en önemli araçtır. Çalışmamızda öğrenciler genel öykü alabilme ve genel fizik muayene becerilerini (vital bulgu değerlendirme, solunum, dolaşım ve batın muayenesi) eğitim sürecinde deneyimleyen ve yapabileceklerini belirtenlerin yüzdesi yüksektir. Öğrencilerin pratisyen hekimlikle ilgili çeşitli alanlarda kendi beceri düzeylerini değerlendirmelerinin istendiği bir başka araştırmada büyük çoğunluğu; hasta ile iletişim kurma, anamnez alma, fizik muayene yapma, laboratuar sonuçları yorumlama, tıbbi ve cerrahi girişim alanlarında kendi beceri düzeylerinin yeterli olduğunu düşünmektedir (18). 2017 yılında Hacettepe Üniversitesi'nde yapılan intörn hekimlerinin mezuniyet sonrası gerek duyacakları mesleki bazı bilgi ve beceriler hakkındaki özdeğerlendirmelerinin incelendiği bir çalışmada katılımcıların \%83'ü kendilerini yeterli hissettiklerini belirtmiştir (21). Özellikli bir yaklaşımı olan psikiyatrik hasta öyküsünü alma konusunda intörn hekimler kendilerini yeterli görmemektedir. Bunun önemli bir nedeni bu beceriyi daha önce deneyimlememiş olmaları olabilir. Aynı zamanda genel fizik muayene becerisi konusunda yeterli olduğunu düşünen intörn hekimler adli olgu, gebe muayenesi, gözdibi muayenesi dahil olmak üzere bazı temel becerilerde kendilerini yeterli olarak görmemişlerdir. Adli olgu muayenesi, olay yeri inceleme ve ölü muayenesinde kendilerini yeterli görmeme sebebi zorunlu bir adli tıp stajının olmayışı ve becerileri de uygulama firsatı bulamıyor olmaları olabilir. Gebe muayenesi ve jinekolojik muayene için yeterli görmeme sebepleri ise üniversite hastanelerinde yapılan normal doğum sayısının az olması ve kadın doğum bölümündeki hasta yoğunluğunun çok fazla olmasından dolayı stajyer ve intörn hekimlere ayrılan eğitim vaktinin yetersiz olması olabilir. Benzer şekilde yenidoğan muayenesi ile ilgili yetersizlik belirtilmiştir. Yenidoğanın özel bir yaş grubu ve enfeksiyona açık bir grup olması nedeniyle bu beceri yeterince deneyimlenememiş olabilir. $\mathrm{Bu}$ tür hasta güvenliğinin öncelenmesi gereken öğrenme süreçlerinde simülasyon uygulamaları ile hastayı risk altında bırakmadan teorik bilgi ve klinik arasında bağ kurulmasını, psikomotor becerilerin geliştirilmesi, karar verme, kritik düşünme ve terapötik iletişim yöntemlerini geliştirilmesi sağlanabilir

Çalışmaya katılanların yarıdan fazlasının meme muayenesini yapmadığını ya da yapamayacağını belirtmiş olması oldukça şaşırtıcıdır. Oysa ki meme muayenesi, özellikle toplumda sık görülen meme kanseri dolayısıyla her hekim tarafından yapılabilmesi beklenen önemli bir beceridir.

\section{Kayit Tutma Raporlama ve Bildirim}

Adli rapor hazırlayabilme ölüm belgesi düzenleyebilme, raporlama ve bildirimi düzenleyebilme becerilerini yapabileceğini belirtenler \%50'nin altındadır. Benzer şekilde Günay'ın çalışmasında araştırmaya katılan intörn hekimlerin yarıdan çoğu adli hekimlik ve resmi yazışmalar alanındaki becerilerini kötü olarak değerlendirmişlerdir (28). Hacettepe Halk Sağlı̆̆g AD. öğrencilerinin yürüttüğü (2017) çalışmada da intörn hekimlerin adli rapor hazırlamada sadece $\% 4,6$ 's1, ölüm belgesi düzenlemede ise $\% 5,7$ 'si kendilerini yeterli bulmaktadır (21). Çalışmada adli olguda fizik muayene becerisindeki zayıflıkla birlikte düşünüldüğünde adli tıp stajının olmayışının bu yetersizliğe neden olduğu şeklinde yorumlanabilir. Tıp eğitiminde, adli tıp, sağlık yönetimi sağlık mevzuatı gibi alanlara önem verilmesi gerekmektedir. Ayrıca hastaları uygun biçimde sevk edebilme gibi hekimden beklenen hasta güvenliğinin temellerinden olan elzem bir beceriyi yapamayacağını ifade eden hekimlerin yaşadıkları mesleki kaygının bir nedeninin de bu yetersizlik hissi olduğu düşünülebilir. Bu konu ile ilgili teorikten ziyade uygulamalı, simülasyon gibi deneyimleyerek kalıcı öğrenmeyi sağlayacak tekniklerin kullanıldığı eğitimlerin düzenlenmesi ihtiyacı vardır.

\section{Laboratuvar Testleri ve İlgili Diğer İşlemler}

Direkt radyografileri okuma ve değerlendirebilme, EKG çekebilme, EKG değerlendirebilme, mikroskop kullanabilme, mikroskopik inceleme için boyalıboyasız preparat hazırlayabilme, mikroskopta preparat inceleyebilme becerilerinde izleme ve yapma yaklaşı olarak $\% 80$ ve üzeri olmasına rağmen yapabilme yüzdelerinin düşük olma sebebi bu becerilerin sadece teknik uygulamasının yanı sıra 
olgular üzerinde çalışma gerektirmesi olabilir. Ayrıca bu başlıktaki bazı becerilerin neredeyse \%20-30 izlendiğini ve yapabilme düzeyinin de bu yüzdelerde kaldığı izlenmiştir. Yapılacak program değerlendirme çalışmaları ile bu becerilerin eğitim programının hangi aşamasında yer aldığının ve neden bu düşüklükte bir sonuç olduğunun araştırılması gerekir.

\section{Girişimsel ve girişimsel olmayan uygulamalar}

Kan basıncı ölçümü becerisi tıp fakültesi eğitiminin başından itibaren sık olarak gözlemleme ve uygulama olanağı bulunan bir beceri olduğu için katılımcıların ileride kan basıncı ölçme konusunda kendilerini yeterli görenlerin yüzdesi yüksektir. Ancak kan transfüzyonu yapabilme becerisini izlediğini belirtenler \%75 olmasına rağmen bu beceriyi uygulama olanağı bulamadıkları için ileride yapabileceğini belirten intörn hekimlerin yüzdesi bu nedenle daha az olabilir. Doğum sonrası anne ve bakımı, gebe ve loğusa izlemi yapabilme düzeyleri oldukça düşüktür. Oysaki gebelik dönemi, doğum eylemi ve lohusalık esnasındaki komplikasyonlar, gelişmekte olan ülkelerde üreme çağındaki kadınlar arasında önde gelen ölüm ve sakatlık nedeni olarak belirtmektedir (39). Anne ve çocuk sağlığının ülke kalkınma hedefleri arasında önemli yer almakta ve Sağlık Bakanlığ tarafından birinci basamaktaki hekimlere bu konularla ilgili sürekli hizmet içi eğitimler düzenlenmektedir. Bu becerilerin hekimlerin sahaya çıkmadan fakülte eğitim programlarında kazandırılması, öğrencilere saha deneyimleri yaşatılması ve ikinci basamak hastaneler ile yapılacak işbirlikleri ile öğrencilerin eğitim ortamlarının zenginleştirilmesi sağlanmalıdır.

Kene çıkartabilme beceri uygulamasını intörn hekimlerin \%70'i izlemediğini, \%79'u daha önce yapmadığını belirmiştir. Özellikle bir dönem epidemik olan ve şu anda daha çok kırsal kesimde görülen hastalıkların tedavisi için gereken becerilerin eğitim programında yer almaması ve mezuniyet öncesinde kırsal hekimlik uygulamalı eğitiminin yeterli sürede olmaması bu sonuçlara neden olmuş olabilir. IM, IV, SC ve ID enjeksiyon yapabilme becerilerinin oldukça yüksek olması eğitim programının erken dönemlerinde kazandırılması ve klinik eğitim sürecinde sık gözlenen ve uygulanan beceriler olması nedeniyle olabilir. Perikardiyosentez yapabilme, plevral ponksiyon yapabilme, suprapubik mesane ponksiyonu yapabilme becerilerini intörn hekimlerin $\% 60$ ve üzerinde izlemediği, \%80 ve üzerinde ise yapmadığı gözlemlenmiştir. Ayrıca bu girişimsel müdahalelerin çekirdek eğitim programındaki temel beceriler içinde yer alması gerekip gerekmediği de tartışılmalıdır. Hastanedeki uygulamalarda da bu becerilerin girişimsel radyoloji gibi özelleşmiş bölümlerde yapılması katılımcıların sonuçlarına etki etmiş olabilir. Lomber ponksiyon yapabilme, mide y1kayabilme, normal spontan doğum yaptırabilme becerilerini katılımcıların neredeyse yarısı yapamayacağını belirtmiştir. Bu durum eğitim programı içerisinde pratik yapabilme imkanının az olması veya bu becerilere yönelik uygun eğitim ortamlarının yaratılmayışı nedeniyle olabilir.

\section{Koruyucu Hekimlik ve Toplum Hekimliği Uygulamaları}

Esnaf ve işyeri denetimi yapabilme ve olağan dışı durumlarda sağlık hizmeti sunabilme becerilerinde izleme ve yapma yüzdelerinin çok düşük olmasının nedeni eğitim programında pratik uygulamaların yer almamasından kaynaklanabilir. Bunlar dışında koruyucu hekimlik ve toplum hekimliği uygulamaları başlığı altındaki diğer beceriler için katılımcılar kendilerini $\% 60$ ve üzerinde yeterli görmektedir. $\mathrm{Bu}$ yüzdenin diğer başlıklara göre düşük olmasına birinci basamak sağlık hizmetlerinde yaşanan dönüşüm ile birlikte halk sağlığı ve toplum hekimliği stajlarının saha uygulamalarının azalması, kuramsal derslerin artması, gerçek ortamında ve bağlamında deneyimlerin azalması olabilir.

Hacettepe Üniversitesi'nde intörn hekimlerle 2001 yılında yapılmış bir çalışmadaki bulgular da tıp fakültesinin eğitim programının, yeni mezun olmuş hekimlerin birincil sağlık hizmetleri için gerekli bilgi ve becerilere kazandırma beklentilerini karşılamadığını göstermiştir. Beşli likert ölçeği puanlamasına göre, bilgi düzeylerinin 2,82 ; beceri düzeyinin 2,44 olduğu yani düşük ve orta arasında olduğu saptanmıştır (16). Hacettepe Tıp Fakültesi 
mezunu hekimlerle yapılan bir başka araştırmada hekimlerin \%38,6'sı tıp fakültesinde aldıkları eğitimin birinci basamak uygulamalar açısından orta düzeyde yeterli olduğunu, \%13,6's1 ise yetersiz olduğunu söylemişlerdir. Hekimlerin \%39,5'i kendilerini birinci basamaktaki hekimlik uygulamaları açısından yetersiz gördüklerini ifade etmiştir (17). Hacettepe Üniversitesinde 2005 yılında intörnlük eğitiminin, mesleki becerilere olan katkısının incelendiği bir çalışmada hekimlik mesleği için olmazsa olmaz uygulamalarla ilgili becerilerin büyük çoğunluğunun, intörnlükte edinildiğini göstermiştir. Becerilerin kazandırılmasında intörnlük dönemi, dolayısıyla yapılandırılmış intörn eğitim programları da çok değerlidir (20). HÜ Halk Sağlığı Anabilim Dalı'nın (2017) yaptığı araştırmada ise katılımcıların \%67,8'i pratisyen hekimlik açısından intörnlük sürecini yararl1/yeterli bulurken \%32,2'si yetersiz bulduğunu belirtmiştir. Katılımcıların çoğu, intörnlük döneminin bilgi düzeylerine olan katkısının \%26-50 aralığında olduğunu; beceri düzeylerine olan katkının \%76-100 aralığında olduğunu belirtmişlerdir (21).

\section{SONUÇ}

Çalışmanın sonuçları değerlendirildiğinde intörn hekimlerin dörtte birinin topluma yararlı olmak için mesleklerini tercih ederken yaklaşık aynı yüzdelerde iş garantisi, mesleki kariyer ve prestij gerekçelerini belirttiği, büyük kısmının uzmanlık yapma isteği bulunduğu görülmektedir. Bu doğrultuda sınav hazırlığı için dershaneye gitme yüzdeleri yüksektir. İntörn hekimlerin yaklaşık yarısı hekimlik uygulamasını başarıyla yapacağı konusunda kaygı hissetmektedir. Acil hastayla baş etme ve hastayla tek başına baş etme bu kaygının dile getirilen en yüksek gerekçesidir. Temel hekimlik uygulamalarını izleme durumlarının, yapma durumlarının ve yapabileceklerine dair inançları incelendiğinde özellikle adli tıp, kadın doğum ve yenidoğan alanlarında yoğunlaşan becerilere yönelik görece daha düşük yüzdeler verildiği görülmüştür. Ulusal Çekirdek Eğitim Programında yer alan bu becerilerin bütününe bakıldığında yaklaşık \%20-25 arasında izleme, yapma, yapabilme durumlarında kayıplar olduğu görülmektedir. $\mathrm{Bu}$ becerilerin UÇEP kapsamında güncellenmesi ve bazı becerilerin kazandırılmasının gerekliliğine ilişkin farklı görüşler söz konusu olsa bile, mezun olacak tüm hekimlerin tamamı tarafından kazanılmış olması beklenir. Bu sebeple yapılacak daha kapsamlı program değerlendirme çalışmaları ile programın planlanması, uygulanması ve değerlendirilmesindeki sorunlar belirlenerek iyileştirilmesine yönelik önlemler geliştirilmelidir. Ayrıca yapılanma sürecinin her aşamasında sürecin öznesi olan öğrenci ve mezun temsiliyetinin olması çok değerlidir. Yapılacak çalışmalar öğrenci, mezun izlemleri ve görüşlerini içermelidir. Bununla birlikte eğitim sürecinde öğrencilerin çekirdek eğitim programında yer alan bu bilgi ve becerilere sahip olmalarının sağlanmasının yanı sıra sahip olanların da kendilerine ilişkin yargılarının olumlu hale getirilmesi ve özgüven kazandırılması önemlidir.

Bu sonuçların araştırmanın bazı sınırlılıkları ile birlikte ele alınması gerekir. Öğrencilerin öz değerlendirmeleri kendi yargıları olması sebebiyle gerçek duruma ilişkin verdiği bilgiler sınırlıdır. Ayrıca bu çalışmada, Hacettepe Üniversitesinde öğrenimleri devam eden intörnlerin \%40'ına ulaşılmış olması nedeniyle sonuçların genellenebilirliği sınırlıdır. Çalışmanın sonuçları bu sınırlılıklarla değerlendirilmelidir.

\section{KAYNAKLAR}

1. World Federation for Medical Education. Report of the World Conference on Medical Education. 1988 http://wfme.org/projects/wfme-publications/99-theedinburgh-declaration/file (Şubat 2018'de ulaşıldı)

2. Institute for International Medical Education. Global Minimum Essential Requirements in Medical Education. Medical Teacher. 2002;24(2):130-135.

3. Sayek, İ., Turan, S., Naçar, M., Akalın, A. ve diğerleri. Mesleklerarası Eğitim. Tıp Eğiticisi El Kitabı. Editör: İskender Sayek Ankara: Güneş Tıp Kitabevi, 2015

4. El-Hassan, K. Students' Ratings of Instruction: Generalizability of Findings. Studies in Educational 
Evaluation. 1995;21(4):411-429.

5. Fresko, B., Nasser, F. Interpreting Student Ratings: Consultation, Instructional Modification, and Attitude towards Course Evaluation. Studies in Educational Evaluation. 2001;27(4):291-305.

6. Wankat \& Oreovicz. Bölüm 16 Evaluation of Teaching. Teaching and Engineering. Purdue University, 1993 https://engineering.purdue.edu/ChE/ aboutus/publications/teaching_eng/Book.pdf (Ocak 2018'de ulaşıldı)

7. Karabilgin, Ö. S., Şahin, H. Eğitim etkinliğini değerlendirmede öğrenci geri bildiriminin kullanımı. Tıp Eğitimi Dünyası. 2006;21(21):27-33.

8. Musal, B., Gursel, Y., Taskiran, H. C., Ozan, S., Tuna, A. Perceptions of first and third year medical students on self-study and reporting processes of problem-based learning. BMC Medical Education. 2004;4(1):16.

9. Sarıkaya, Ö., Gülpınar, M. A., Keklik, D., Kalaça, S. Öğrencilerin sesini dinlemek: Eğitimin öğrenciler tarafından değerlendirilmesi. Tıp Eğitimi Dünyası. 2002;9(9):6-12.

10. Turhan, K., Yaris, F., Nural, E. Does instructor evaluation by students using a web-based questionnaire impact instructor performance?. Advances in Health Sciences Education. 2005;10(1):5-13.

11. Jackson, D. L., Teal, C. R., Raines, S. J., Nansel, T. R., Force, R. C., Burdsal, C. A. The dimensions of students' perceptions of teaching effectiveness. Educational and Psychological Measurement.1999;59(4):580-596.

12. Marsh, H. W., Roche, L. A. Making students' evaluations of teaching effectiveness effective: The critical issues of validity, bias, and utility. American Psychologist. 1997;52(11):1187-1197.
13. Ramalingaswami, P. Specialty choice of medical students in India. MedicalEducation. 1987;21(1):53-58.

14. Thistlethwaite, J. E., Ewart, B. R. Valuing diversity: helping medical students explore their attitudes and beliefs. Medical Teacher. 2003;25(3):277-281.

15. TBMM Araştırma Komisyonu. Türkiye'de tıp eğitimi öğrenci boyutu. Cilt 1 Ankara, 1991

16. Özvariş, S., Sönmez, R., Sayek, I. Assessment of knowledge and skills in primary health care services: senior medical students' self-evaluation. Teaching and Learning in Medicine.2004;16(1):34-38.

17. Üner, S., Özvarış, Ş. B., Turan, S., Arıöz, U., Odabaşı, O., Elçin, M., Sayek, İ. Ankara'da birinci basamak sağlık kurumlarında çalışan hekimlerin sunulan hizmetlere ilişkin öz değerlendirmeleri. Sürekli Tıp Eğitimi Dergisi. 2005;14:143.

18. Günay, O. Erciyes Üniversitesi Tıp Fakültesi son sınıf öğrencilerinin tıp eğitimi hakkındaki düşünceleri. Tıp Eğitimi Dünyası. 2002;7(7).

19. Hacettepe Üniversitesi Halk Sağlığı Anabilim Dalı. Dönem IV Öğrencilerinin İntörnlük Eğitimi Başındaki Mesleki Becerilerinin Saptanması. Yayınlanmamış İntörn Araştırması. Hacettepe Üniversitesi, Ankara 2005 .

20. Telatar, T. G., Özsırkıntı, H., Temel, T., Arslan, S., Polat, H., Yaşa, Z., Güler, Ç. (2005). Dönem VI öğrencilerinin intörn hekimlük eğitimi sonundaki mesleki beceri düzeylerinin saptanması. Hacettepe Tip Dergisi, 36, 239-47.

21. Hacettepe Üniversitesi Halk Sağllğı Anabilim Dal1. 2017-2018 İntörn hekimlerinin mezuniyet sonrası gerek duyacakları mesleki bazı bilgi ve beceriler hakkındaki özdeğerlendirmeleri: kesitsel bir çalışma. Yayınlanmamış İntörn Araştırması. Hacettepe Üniversitesi, Ankara, 2017.

22. Alper, Z., Özdemir, H. Uludağ üniversitesi tıp 
fakültesini tercih eden öğrencilerin kimi sosyodemografik özellikleri ve mesleğe bakış açıları. Uludağ Üniversitesi Tıp Fakültesi Dergisi. 2004;30(2):93-96.

23. Açık, Y., Oğuzöncül, F., Polat, S. A., Güngör, Y., Güngör, L. Firat Üniversitesi Tip Fakültesi öğrencilerinin tıp eğitimi ve mezuniyet sonrası hakkındaki düşünceleri. Toplum ve Hekim. 2002;17(3):195-201.

24. Köksal vd. Cerrahpaşa Tıp Fakültesi Öğrencilerinin

Tıp Eğitimi Ve Mezuniyet Sonrası İle İlgili Tutumları. Cerrahpaşa Tıp Dergisi. 1999;30(4).

25. Kasapoğlu A. Tıp Eğitimi; Uygulamalı ve Sosyolojik bir araştırma. Ankara: Ankara Üniversitesi Basımevi, 1992.

26. Bakır B. Bir tıp fakültesi öğrencilerinin mezuniyet sonrası beklentileri. Toplum ve Hekim. 1994;9(60):6367

27. Turan S. Üner S. Preparation for a Postgraduate Specialty Examination by Medical Students in Turkey: Processes and Sources of Anxiety. Teaching and Learning in Medicine. 2015;27(1):27-36.

28. Yüksek Öğretim Kurulu Başkanlığı. Mezuniyet Öncesi Tıp Eğitimi-Ulusal Çekirdek Eğitim Programı-2014 Rehberi. Yüksek Öğretim Kurulu, Ankara, 2104.

29. Terzi C, Saçaklığlu F, Sayek . Yılında Türkiye'de Tıp Eğitimi. 2000-2020 Sürecinde Nasıl Bir Dünya, Türkiye, Sağlık, Tıp Ortamı Öngörülebilir, Oluşturulabilir? Ankara: TTB Yayını, 2002.

30. Canbaz, S., Sünter, A. T., Aker, S., Pekşen, Y. Tıp fakültesi son sınıf öğrencilerinin kaygı düzeyi ve etkileyen faktörler. Genel Tip Dergisi. 2007;17(1):1519.

31. Kılıç, B., Sayek İ. Türk tabipleri birliği mezuniyet öncesi tıp eğitimi raporu-2000 (TTB-MÖTER). Toplum ve Hekim.2001;16:230-40.
32. Werner, L. S., Bull, B. S. The effect of three commercial coaching courses on Step One USMLE performance. Medical education.2003;37(6):527-531.

33. Strowd, R. E., Lambros, A. Impacting student anxiety for the USMLE Step 1 through processoriented preparation. Medical education online. 2010;15(1):4880.

34. Tempski, P., Bellodi, P. L., Paro, H. B., Enns, S. C., Martins, M. A., Schraiber, L. B. What do medical students think about their quality of life? A qualitative study. BMC medical education.2012;12(1):106.

35. Yalçınoğlu N., Kayı İ., Işık Ş., Aydın T., Zengin Ş., Karabey S. İstanbul Üniversitesi İstanbul Tıp Fakültesi Son Sınıf Öğrencilerinin Tıp Eğitimi İle İlgili Görüşleri. İstanbul Tıp Fakültesi Dergisi.2012;75(3):41-45.

36. Mayda A., Yılmaz M., Bolu F., Deler M., Demir H., Doğru M., Fırat A., Güksu S. Bir tıp fakültesi 4, 5 ve 6 . sınıf ögrencilerinde gelecek ile ilgili kayg1 durumunun değerlendirilmesi. Düzce Üniversitesi Sağlık Bilimleri Enstitüsü Dergisi. 2014;4(3):7-13.

37. Yeniçeri, N., Mevsim, V., Özçakar, N., Özan, S., Güldal, D., Başak, O. Tıp eğitimi son sınıf öğrencilerinin gelecek meslek yaşamları ile ilgili yaşadıkları anksiyete ile sürekli anksiyetelerinin karşılaştırılması. Dokuz Eylül Üniversitesi Tıp Fakültesi Dergisi. 2007;21(1):19-24.

38. Terzioğlu, F., Boztepe, H., Duygulu, S., Tuna, Z., Kapucu, S., Özdemir, L. Simulasyon eğitiminin önemli bir bileşeni: çözümleme. Cumhuriyet Hemşirelik Dergisi. 2013;2(2):57-63.

39. Türkiye Halk Sağlığı Kurumu (THSK). Doğum Öncesi Bakım Yönetim Rehberi, 2014 